\title{
SINTESIS BIOKOAGULAN BERBASIS KITOSAN LIMBAH SISIK IKAN BANDENG DAN APLIKASINYA TERHADAP NILAI BOD DAN COD LIMBAH TAHU DI KOTA TARAKAN
}

\author{
Stephanie Bija ${ }^{1 \star}$, Yulma $^{1}, \operatorname{Imra}^{1}$, Aldian $^{1}$, Akbar Maulana $^{1}$, Anhar Rozi $^{2}$ \\ ${ }^{1}$ Fakultas Perikanan dan Ilmu Kelautan, Universitas Borneo Tarakan \\ Jalan Amal Lama No.1, Tarakan 77115 Kalimantan Utara, Indonesia Telepon 0811-5307-023 \\ ${ }^{2}$ Fakultas Perikanan dan Ilmu Kelautan, Universitas Teuku Umar \\ Jalan Alue Penyareng, Meulaboh 23615 Aceh Barat, Indonesia Telepon (0655) 7110535 \\ *Korespondensi : bijastephanie92@gmail.com \\ Diterima: 25 November 2019/ Disetujui: 25 Maret 2020
}

Cara sitasi: Bija S, Yulma, Imra, Aldian, Maulana A, Rozi A. 2020. Sintesis biokoagulan berbasis kitosan limbah sisik ikan bandeng dan aplikasinya terhadap nilai BOD dan COD limbah tahu di Kota Tarakan. Jurnal Pengolahan Hasil Perikanan Indonesia. 23(1): 86-92.

\begin{abstract}
ABSTRAK
Biokoagulan merupakan koagulan alami yang berperan untuk mengikat kotoran yang terdapat di dalam limbah tahu. Sumber biokoagulan dapat berasal dari kitosan sisik ikan bandeng.Penelitian ini menentukan penurunan nilai BOD dan COD pada limbah tahu melalui biokoagulasi kitosan dari limbah sisik ikan bandeng. Metode yang digunakan dalam pembuatan kitosan melalui tahap deproteinasi $(\mathrm{NaOH}$ $0,1 \mathrm{~N}$ selama 2 jam pada suhu $65^{\circ} \mathrm{C}$ ), demineralisasi ( $\mathrm{HCl} 1 \mathrm{~N}$ selama 30 menit pada suhu ruang), dan deasetilasi $\left(\mathrm{NaOH} 20 \%\right.$ selama 1 jam pada suhu $\left.121^{\circ} \mathrm{C}\right)$. Karakteristik kitosan berupa derajat deasetilasi memiliki nilai 44\%. Aplikasi kitosan sebagai biokoagulan dilakukan dengan prinsip koagulasi-flokulasi dengan penambahan larutan kitosan pada konsentrasi 10 ppm, 20 ppm, dan 30 ppm pada limbah tahu. Hasil penelitian menunjukkan adanya penurunan terhadap nilai BOD dan COD setelah penambahan kitosan 10 ppm, 20 ppm, dan 30 ppm. Perlakuan dengan penambahan kitosan 30 ppm merupakan perlakuan terbaik dengan nilai BOD yaitu $7 \mathrm{mg} / \mathrm{L}$ dan nilai COD yaitu $5600 \mathrm{mg} / \mathrm{L}$.
\end{abstract}

Kata Kunci : deproteinasi, derajat deasetilasi, koagulasi.

\section{Biochoagulant Synthesis Based on Chitosan from Bandeng Fishing Waste and Its Application of Reduction of BOD and COD Value of Tofu Waste In Tarakan City}

\begin{abstract}
Biocoagulant is a natural coagulant that has role to purify contaminated water, such as from tofu waste. Biocoagulant can be obtained from chitosan which made from milkfish scales. The purpose of this study was to determine chitosan from milkfish scales waste as biocoagulant to reduce BOD and COD value in Tofu waste. The method used in making chitosan through three stages, first deproteination $(\mathrm{NaOH} 0,1$ $\mathrm{N}$ for 2 hours at $65^{\circ} \mathrm{C}$ ), followed by demineralization ( $\mathrm{HCl} 1 \mathrm{~N}$ for 30 minutes at room temperature), and deacetylation $\left(\mathrm{NaOH} 20 \%\right.$ for 1 hours at $\left.121^{\circ} \mathrm{C}\right)$. The characteristic of deacetylation degree of chitosan was $44 \%$. Application of chitosan as bio coagulant carried out with coagulation-flocculation principle with the addition of chitosan solution at $10 \mathrm{ppm}, 20 \mathrm{ppm}$, and $30 \mathrm{ppm}$ in tofu waste. The results showed a decrease in the value of BOD and COD after the addition of chitosan $10 \mathrm{ppm}, 20 \mathrm{ppm}$, and $30 \mathrm{ppm}$. The addition of 30 ppm chitosan was the best treatment with a BOD value of $7 \mathrm{mg} / \mathrm{L}$ and COD value of $5600 \mathrm{mg} / \mathrm{L}$.
\end{abstract}

Keywords : coagulation, degree of deacetylation, deproteination. 


\section{PENDAHULUAN}

Tahu merupakan makanan yang terbuat dari bahan dasar kedelai, umumnya dikonsumsi sebagai lauk atau dijadikan cemilan. Produksi tahu di Indonesia dominan dilakukan secara tradisional dan menghasilkan hasil samping pengolahan berupa limbah padat maupun cair. Limbah cair dari hasil pembuatan tahu secara tradisional umumnya langsung dibuang ke perairan karena belum ada sistem yang dapat mengatur pembuangan limbah tersebut. Hal ini berdampak terhadap kualitas air perairan karena air buangan industri tahu mengandung zat-zat organik yang melebihi standar mutunya, di antaranya nilai biochemical oxygen demand (BOD) $6586 \mathrm{mg} / \mathrm{L}$ dan chemical oxygen demand (COD) 8640 mg/L (Myrasandri dan Syafila 2009). Nilai BOD dan COD yang harus dipenuhi sesuai standar yaitu $150 \mathrm{mg} / \mathrm{L}$ dan $300 \mathrm{mg} / \mathrm{L}$ (KLH 2014). Limbah tahu yang kandungan zat nya melebihi baku mutu bila terbuang terus-menerus ke perairan, maka akan menimbulkan aroma tidak sedap hingga kematian terhadap biota perairan.

Industri tahu sebagian besar belum dilengkapi dengan unit pengolah air limbah sehingga masih banyak gas-gas yang ditemukan di antaranya gas oksigen, nitrogen, amonia, hidrogen sulfida, metana, dan karbondioksida. Gas-gas tersebut merupakan hasil penguraian dari senyawa organik yang terdapat pada limbah cair sehingga proses pengolahan limbah perlu dilakukan agar memenuhi standar limbah tahu buangan yang akan dibuang ke saluran umum (Ruhmawati et al. 2017; Yudhistira et al. 2016). Salah satu metode yang efisien untuk mengolah limbah tahu agar memenuhi standar air buangan yaitu melalui proses koagulasi dengan pemanfaatan biokoagulan.

Biokoagulan merupakan koagulan alami yang dapat berperan dalam proses sedimentasi partikel-partikel kecil yang sulit mengendap dengan sendirinya. Biokoagulan berfungsi untuk mengikat kotoran atau partikel-partikel yang terdapat di dalam air (Suharto 2011). Beberapa penelitian telah membuktikan bahwa pemanfaatan koagulan alami untuk menjernihkan air limbah dapat menggunakan biji asam jawa, biji kelor, dan biji kecipir (Yuliastri 2010;
Syamsumarsih 2011). Biokoagulan lainnya dapat diperoleh dari kitosan yang merupakan turunan dari kitin. Kitosan dapat dimanfaatkan sebagai biokoagulan yang ramah lingkungan karena sifatnya yang mudah untuk terdegradasi (Wardhani et al. 2014). Hal ini didasarkan pada keberadaan gugus aktif amina $\left(\mathrm{NH}_{2}\right)$. Gugus amina memiliki pasangan elektron bebas dari atom hidrogen sehingga gugus tersebut dapat mengikat ion-ion logam, disebabkan gugusnya bersifat sangat reaktif dan elektronegatif.

Beberapa penelitian yang memanfaatkan kitosan sebagai biokoagulan telah dilakukan diantaranya oleh Meicahayanti et al. (2018) bahwa kitosan mampu berperan sebagai koagulan limbah cair tekstil dan penelitian oleh Ihsani et al. (2014) yang menggunakan kitosan sebagai koagulan dalam pengolahan air sungai yang tercemar limbah industri jamu. Bahan dasar pembuatan kitosan dapat dilakukan dengan memanfaatkan sisik ikan karena mengandung kitin. Kandungan kitin pada sisik ikan laut yang telah kering umumnya sebesar $20-30 \%$ kitin, 30-50\% mineral, dan $30-40 \%$ protein (Kumari 2014). Pemanfaatan sisik ikan sebagai kitosan dapat meningkatkan nilai ekonomi dari sisik ikan yang sampai saat ini tidak termanfaatkan dengan baik dan hanya menimbulkan masalah lingkungan misalnya bau yang tak sedap dan meningkatnya bakteri di sekitar daerah pembuangan. Salah satu limbah sisik ikan yang belum banyak dimanfaatkan adalah sisik ikan bandeng.

Sisik ikan bandeng merupakan limbah yang sangat jarang dimanfaatkan dan jumlahnya sangat banyak karena ikan bandeng merupakan komoditi unggulan perikanan di Tarakan, Kalimantan Utara, selain udang, kepiting, dan rumput laut. Penggunaan biokoagulan berbasis kitosan mempunyai beberapa keunggulan, yaitu sifatnya yang terbarukan, bersifat polielektronik, tidak beracun, mudah terdegradasi maupun berinteraksi dengan senyawa organi, seperti protein (Renault et al. 2009; Sinardi et al. 2013; $\mathrm{Li}$ et al. 2016).

Biokoagulan berbasis kitosan yang dibuat dari limbah sisik ikan bandeng diharapkan adalah koagulan yang aman, mempunyai added value yang tinggi, dan ramah 
lingkungan. Berdasarkan uraian tersebut perlu dilakukan penelitian mengenai pembuatan biokoagulan berbasis kitosan dari limbah sisik ikan bandeng untuk pengolahan limbah tahu di Kota Tarakan. Penelitian ini bertujuan untuk menentukan penurunan nilai BOD dan COD pada limbah tahu melalui biokoagulasi kitosan dari limbah sisik ikan bandeng.

\section{BAHAN DAN METODE Bahan dan Alat}

Bahan yang digunakan pada penelitian ini adalah limbah sisik bandeng yang didapatkan di Pasar Gusher dan sampel limbah cair industri tahu di Kelurahan Karang Anyar, akuades (Waterone), natrium hidroksida $0,1 \mathrm{~N}$ dan 20\% (Merck), natrium klorida (Merck), natrium tiosulfat (Merck), kalium dikromat (Merck), indikator ferroin (Merck), asam asetat (Merck), dan asam sulfat (Merck). Alat yang digunakan selama penelitian adalah tabung winkler, aerator, $\mathrm{COD}$ reactor, portable pH meter (Myron LARHI), magnetic stirrer (Heidolph MR $3001 \mathrm{~K}$ ), instrumen spektrofotometri FTIR (Shimadzu 2000),).

\section{Metode Penelitian \\ Persiapan sampel}

Limbah sisik ikan berasal dari dari pengolahan ikan bandeng tanpa duri (baduri) di Pasar Gusher. Sisik ikan yang dikumpulkan memiliki berat kotor berkisar $4 \mathrm{~kg}$. Limbah sisik ikan yang telah dikumpulkan selanjutnya dicuci dengan sabun untuk memisahkan limbah sisik ikan dengan kotoran lainnya. Pada tahap ini, limbah sisik ikan lalu dikeringkan dengan oven, kemudian diblender hingga halus dan diayak sehingga dihasilkan serbuk sisik ikan bandeng.

\section{Pembuatan kitosan}

Pembuatan kitosan mengacu pada Ifa et al. (2018) dengan modifikasi, melalui tiga tahap yaitu deproteinasi, demineralisasi, dan deasetilasi. Tahap deproteinasi menambahkan larutan $\mathrm{NaOH} 0,1 \mathrm{~N}$ pada endapan sisik bandeng yang telah dikeringkan pada perbandingan 1:10 (b/v), dipanaskan dan di stirer pada suhu $65^{\circ} \mathrm{C}$ selama 2 jam secara konstan, kemudian disaring. Tahap kedua yaitu demineralisasi, serbuk sisik ikan bandeng ditambahkan $\mathrm{HCl} 1 \mathrm{~N}(1: 10 \mathrm{~b} / \mathrm{v})$ pada suhu ruang selama 30 menit. Larutan disaring, endapan yang dihasilkan dibilas dengan akuades hingga $\mathrm{pH}$ netral kemudian dikeringkan dan disebut sebagai kitin. Kitin dilakukan deasetilasi untuk mendapatkan kitosan dengan cara melarutkannya dalam $\mathrm{NaOH} 20 \%(1: 10$ b/v) selama 1 jam pada suhu $121^{\circ} \mathrm{C}$. Sampel selanjutnya dinetralisasi sampai diperoleh $\mathrm{pH}$ netral, lalu di oven sehingga menjadi kitosan dan dianalisis karakteristiknya.

\section{Pembuatan larutan kitosan}

Pembuatan larutan kitosan untuk dijadikan koagulan dilakukan mengacu pada Prayudi dan Susanto (2000) dengan cara melarutkan kitosan sebanyak 1 gram di dalam $20 \mathrm{~mL}$ asam asetat $2 \%$, lalu akuades ditambahkan hingga $100 \mathrm{~mL}$, kemudian larutan diaduk. Proses pengadukan menggunakan pengaduk magnetik agar kitosan dapat larut sempurna.

\section{Penambahan biokoagulan kitosan ke dalam limbah tahu (modifikasi metode Muruganandam et al. 2017; Ratnawulan 2018)}

Sampel limbah tahu terlebih dahulu diukur BOD dan COD-nya. Aplikasi kitosan sebagai biokoagulan dilakukan dengan metode Jartest Flocculator SW1 (Stuart Scientific) menggunakan pengaduk atau alat flokulator (Muruganandam et al. 2017). Proses koagulasi-flokulasi dilakukan dengan cara: limbah tahu masing-masing ditambahkan larutan kitosan dengan konsentrasi $10 \mathrm{ppm}$, 20 ppm, 30 ppm, dan kontrol tanpa larutan kitosan ke dalam sampel limbah tahu sebanyak $500 \mathrm{~mL}$. Pengadukan cepat $200 \mathrm{rpm}$ selama 1 menit, dilanjutkan pengadukan lambat 50 rpm selama 30 menit. Proses selanjutnya yaitu agitasi dengan selang waktu 30 menit lalu difiltrasi. Hasil filtrasi dianalisis, meliputi pengukuran BOD dan COD.

\section{Karakterisasi kitosan Derajat deasetilasi}

Derajat deasetilasi pada kitosan dihitung dengan metode base line berdasarkan spektrum IR, dengan rumus: 


$$
\mathrm{DD}=100-\left[\left(\frac{A_{1655}}{A_{3450}}\right) \times 115\right]
$$

\section{Karakterisasi limbah tahu Analisis BOD (Prayudi dan Susanto 2000)}

Limbah tahu diaerasi selama 15 menit, kemudian ditambahkan nutrisi dengan kandungan fosfor dan nitrogen, selanjutnya ke dalam 2 buah botol dimasukkan masing-masing sampel dan dilakukan pengukuran nilai oksigen terhadap salah satu botol, sedangkan btol lainnya diinkubasi pada suhu $20^{\circ} \mathrm{C} \pm 1^{\circ} \mathrm{C}$ selama 5 hari.

\section{Analisis COD (Prayudi dan Susanto 2000)}

Sebanyak $10 \mathrm{ml}$ sampel air limbah dimasukkan ke dalam erlenmeyer, lalu ditambahkan larutan $\mathrm{K}_{2} \mathrm{Cr}_{2} \mathrm{O}_{7}$ sebanyak 5 $\mathrm{mL}$. Larutan kemudian diberi penambahan asam sulfat sebanyak $15 \mathrm{~mL}$ dan diaduk. Erlenmeyer yang dipakai sebagai wadah, ditutup menggunakan kaca penutup dan didiamkan selama 30 menit. Campuran ditambahkan 7,5 $\mathrm{mL}$ aquades sehingga encer, lalu diberi indikator ferroin sebanyak 2-3 tetes. Proses selanjutnya yaitu titrasi larutan hingga terjadi perubahan warna dari kuning oranye atau biru kehijauan menjadi merah cokelat menggunakan FAS (Ferrous Ammonium Sulfat) untuk menghitung nilai COD.

\section{HASIL DAN PEMBAHASAN Karakteristik Kitosan dari Limbah Sisik Ikan Bandeng}

Serbuk kitosan yang dihasilkan mempunyai warna putih, tidak berbau, dan mudah larut dalam larutan asam asetat. Nilai derajat deasetilasi (DD) kitosan dari limbah sisik ikan bandeng yaitu 44\%. Hasil penelitian belum memenuhi standar mutu komersial dari Protan Laboratories Inc. (1987). Proses optimasi deasitilasi pada kitosan mepengaruhi pada nilai DD (Azhar et al. 2010). Kemampuan koagulan untuk dapat membentuk flok bergantung pada derajat deasetilasi. Nilai derajat deasetilasi yang semakin tinggi mengakibatkan gugus amino $\left(\mathrm{NH}_{2}\right)$ akan semakin banyak pada molekul kitosan sehingga sifat kitosan menjadi lebih reaktif (Mursida et al. 2018). Nilai DD kitosan dari limbah sisik ikan bandeng tergolong rendah sehingga aplikasinya sebagai koagulan perlu menggunakan dosis kitosan dalam jumlah besar.

Penelitian serupa yang telah dilakukan oleh Sinardi et al. (2013) mengemukakan bahwa kitosan dari cangkang kerang hijau memiliki derajat deasetilasi yaitu 38,91\%, tetapi dapat digunakan sebagai koagulan penjernih air dengan penggunaan dosis kitosan sebanyak $250 \mathrm{mg} / \mathrm{L}$ sehingga diperoleh tingkat penyisihan kekeruhan sebesar 92,6\%. Nilai derajat deasetilasi tergolong rendah, tetapi dosis yang ditambahkan besar sehingga kitosan dapat membentuk flok pada proses koagulasi-flokulasi.

\section{Karakteristik Limbah Industri Tahu}

Karakteristik limbah tahu dilakukan dengan menganalisis parameter kimia, diperoleh nilai untuk semua parameter melebihi nilai baku mutunya. Parameter yang dianalisis meliputi nilai BOD dan COD. Hasil karakteristik limbah tahu tertera pada Table 1.

Table 1. Characteristic of tofu waste

\begin{tabular}{ccc}
\hline Parameter & $\begin{array}{c}\text { Concentration } \\
(\mathrm{mg} / \mathrm{L})\end{array}$ & $\begin{array}{c}* \text { Tofu wastewater } \\
\text { quality standard } \\
(\mathrm{mg} / \mathrm{L})\end{array}$ \\
\hline BOD & $225 \pm 4.00$ & 150 \\
COD & $7600 \pm 4.73$ & 300 \\
\hline *
\end{tabular}

${ }^{\star}$ Regulation of Ministry of Environment

Analisis awal yang dilakukan pada limbah tahu yang belum diberi penambahan kitosan menunjukkan nilai BOD dan COD tidak memenuhi standar yang telah ditetapkan dalam Peraturan Menteri Lingkungan Hidup No.5 Tahun 2014. Rasio nilai COD dan BOD yang tinggi pada limbah cair tahu menunjukkan bahwa limbah tersebut bersifat organik sehingga mikroorganisme membutuhkan oksigen dalam jumlah besar untuk menguraikan senyawa-senyawa organik tersebut (Husin 2003). Limbah cair tahu mengandung sedikit senyawa anorganik, sedangkan senyawa organiknya tinggi (Ratnani (2011). Nilai kedua parameter yang tinggi ini diduga terjadi karena berkurangnya 


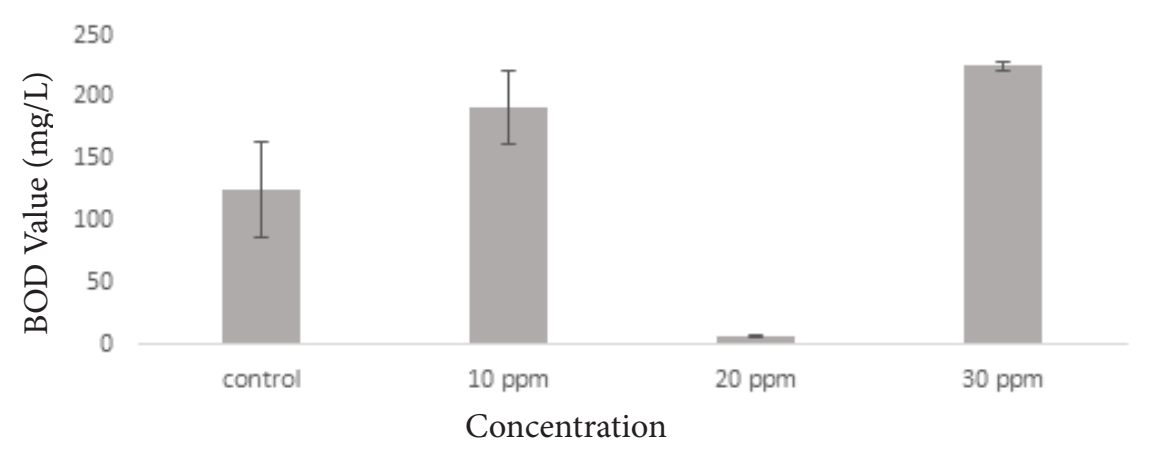

Figure 1 BOD of tofu waste after the addition of chitosan-based biocoagulant

oksigen selama oksidasi. Salah satu faktor yang mempengaruhi berkurangnya oksigen adalah sifat mikroorganisme aerob yang memakai oksigen dalam jumlah banyak untuk menghasilkan energi sehingga dapat menguraikan bahan organik yang tinggi (Muhajir 2013). Mikroorganisme aerob akan menguraikan zat organik jika oksigen terlarut sudah tidak tersedia sehingga mengeluarkan gas metana dan gas asam sulfida yang berbau seperti telur busuk sehinga secara fisik limbah tahu mempunyai bau yang sangat menyengat (Khiatuddin 2003).

\section{Pengaruh pada Biochemical Oxygen Demand (BOD)}

Nilai BOD limbah tahu yang telah diberi penambahan kitosan dengan konsentrasi berbeda mengalami penurunan, tetapi terjadi kenaikan pada konsentrasi kitosan 30 ppm. Nilai BOD tersaji pada Figure 1.

Limbah cair tahu memiliki BOD awal yang sangat tinggi yaitu $125 \mathrm{mg} / \mathrm{L}$, tapi cenderung menurun dengan penambahan kitosan yakni pada konsentrasi $10 \mathrm{ppm}$ dan $20 \mathrm{ppm}$ dan telah memenuhi standar baku mutunya. Kecenderungan penurunan ini diindikasikan terjadi karena bahan-bahan organik pada limbah tahu dapat terdegradasi secara biologis (Muhajir 2013). Penambahan kitosan dengan konsentrasi $30 \mathrm{ppm}$, terjadi kenaikan nilai BOD sehingga tidak memenuhi standar baku mutunya. Kenaikan ini diduga terjadi karena kitosan yang digunakan masih memiliki DD yang masih rendah sehingga penyerapan BOD tidak optimal.

\section{Pengaruh pada (COD)}

Chemical Oxygen Demand atau COD merupakan banyaknya oksigen yang digunakan untuk mengoksidasi senyawa organik melalui proses kimia. Limbah tahu yang telah diberi penambahan kitosan pada konsentrasi berbeda menunjukkan nilai COD semakin menurun. Nilai COD dapat dilihat pada Figure 2.

Kandungan COD pada limbah tahu semakin menurunseiring dengan penambahan kitosan, tetapi mengalami kenaikan kembali pada konsentrasi $30 \mathrm{ppm}$. Penurunan pada konsentrasi 20 ppm terjadi karena kitosan mempunyai sifat polielektrolit kation. Kitosan dapat dipakai sebagai biokoagulan yang dapat menghilangkan komponen-komponen

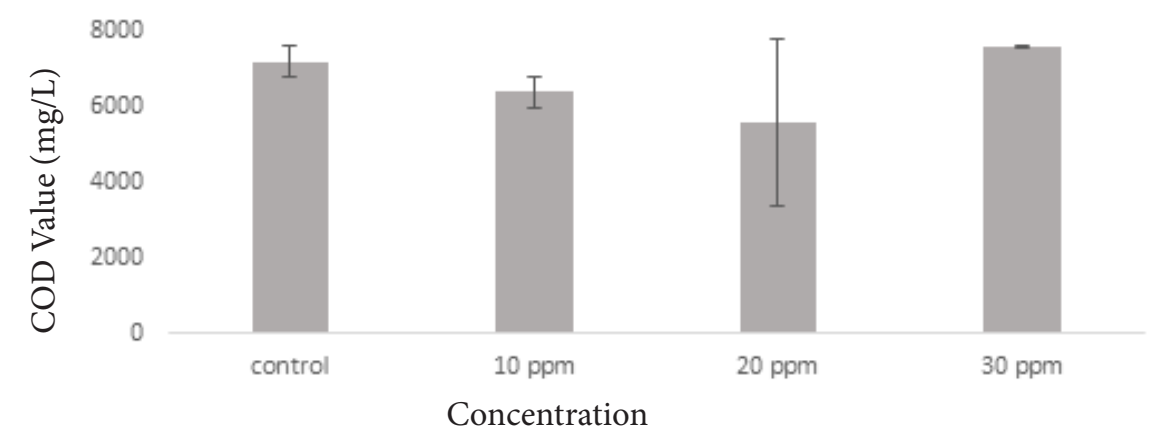

Figure 2 COD of tofu waste after the addition of chitosan-based biocoagulant 
pengotor yang terlarut karena mempunyai karakteristik sebagai penghubung agregat, densitas muatan positif tinggi, pengendapan pada $\mathrm{pH}$ basa maupun netral, dan memiliki rantai polimer panjang (Renault et al. 2009).

Penambahan kitosan sebagai koagulan dengan berbagai konsentrasi yang berbeda dapat menurunkan nilai COD karena adanya penyisihan bahan-bahan organik berupa padatan koloid dalam limbah tahu (Nasution et al. 2015). Penurunan nilai COD belum memenuhi standar baku mutunya (300 mg/L). Penurunan ini diduga karena jumlah oksigen terlarut untuk mengoksidasi senyawa organik yang terdapat di dalam limbah tahu sudah mulai berkurang. Oksigen dapat berkurang diakibatkan salah satu faktor yakni keberadaan bakteri yang menggunakan oksigen tersebut untuk proses pembusukannya (Muhajir 2013). Faktor lain yang juga mempengaruhi adalah dosis kitosan yang digunakan rendah. Pemberian dosis koagulan yang tepat pada pengolahan limbah cair dapat mempengaruhi penurunan nilai COD (Farihin et al. 2015).

\section{KESIMPULAN}

Kitosan dengan konsentrasi 20 ppm menunjukkan perubahan terhadap kualitas limbah tahu yang semakin mendekati nilai baku mutunya. Nilai COD masih berada di bawah nilai standarnya, sedangkan nilai BOD telah memenuhi standar mutunya. Kitosan dari limbah sisik ikan bandeng dapat memperkualitas limbah tahu dan optimal jika memiliki nilai DD yang sesuai standar mutu.

\section{UCAPAN TERIMA KASIH}

Pembiayaan keseluruhan penelitian penulis berasal dari Sumber Dana DIPA Universitas Borneo Tarakan Tahun 2019 berdasarkan surat keputusan No. 072/UN51.9/ TU/2019.

\section{DAFTAR PUSTAKA}

Azhar M, Efendi J, Syofyeni E, Lesi RM, Sri N. 2010. Pengaruh konsentrasi $\mathrm{NaOH}$ dan $\mathrm{KOH}$ terhadap derajat deasetilasi kitin dari limbah kulit udang. EKSAKTA. 1(10):1-8.

Farihin FM, Wardhana IW, Sumiyati S.
2015. Studi penurunan COD, TSS, dan Turbidity dengan menggunakan kitosan dari limbah cangkang kerrang hijau (Perna viridis) sebagai biokoagulan dalam pengolahan limbah cair PT.Sido Muncul Tbk, Semarang. Jurnal Teknik Lingkungan. 4(1):1-9.

Husin A. 2003. Pengolahan limbah cair industri tahu menggunakan biji kelor (Moringa oleifera seeds) sebagai koagulan. Laporan penelitian dosen muda, Fakultas Teknik USU. Medan.

Ifa L, Artiningsih A, Julniar, Suhaldin. 2018. Pembuatan kitosan dari sisik ikan kakap merah. Journal of Chemical Process Engineering. 3(1): 47-50.

Ihsani SL, Widyastuti CR. 2014. Sintetis biokoagulan berbasis kitosan dari kulit udang untuk pengolahan air sungai yang tercemar limbah industri jamu dengan kandungan padatan tersuspensi tinggi. Jurnal Bahan Alam Terbarukan. 3(2):3339.

Khiatuddin M. 2003. Melestarikan sumberdaya air dengan teknologi rawa buatan. Yogyakarta (ID): Gadjah Mada University Press.

Kumari S, Rath PK. 2014. Extraction and characterization of chitin and chitosan from (labeo rohit) fish scales. Procedia Materials Science. 6:482- 489.

Li A, Lin R, Lin C, He B, Zheng T, Lu L, Cao Y. 2016. An environment-friendly and multi-functional absorbent from chitosan for organic pollutants and heavy metal ion. Carbohydrate Polymers. 148: 272-280.

Meicahayanti I, Marwah, Setiawan Y. 2018. Efektivitas kitosan limbah kulit udang dan alum sebagai koagulan dalam penurunan TSS limbah cair tekstil. Jurnal Chemurgy. 2(1):1-5.

Muhajir MS. 2013. Penurunan limbah cair bod dan cod pada industri tahu menggunakan tanaman cattail (Typha angustifolia) dengan sistem constructed wetland. [skripsi]. Semarang (ID): Universitas Negeri Semarang.

Mursida, Tasir, Sahriawati. 2018. Efektivitas larutan alkali pada proses deasetilasi dari berbagai bahan baku kitosan. Jurnal Pengolahan Hasil Perikanan Indonesia. 


$$
\text { 21(2):356-366. }
$$

Muruganandam L, Kumar MPS, Jena A, Gulla S, Godhwani B. 2017. Treatment of waste water by coagulation and flocculation using biomaterials. IOP Conf. Series: Materials Science and Engineering. 263: 1-11.

Myrasandri P, Syafila M. 2012. Potensi pembentukan produk hasil degradasi senyawa organik limbah cair tahu menggunakan anaerobic baffled reactor lima kompartemen. Jurnal Teknik Lingkungan. 18(1):75-86.

Nasution P, Sumiyati S, Wardana IW. 2015. Studi penurunan TSS, Turbidity, dan COD dengan menggunakan kitosan dari limbah cangkang keong sawah (Pila ampullacea) sebagai biokoagulan dalam pengolahan limbah cair PT.Sido Muncul, Tbk Semarang. Jurnal Teknik Lingkungan. 4(1):1-10.

Prayudi T, Susanto JP. 2000. Chitosan sebagai bahan koagulan limbah cair industri tekstil. Jurnal Teknologi Lingkungan. 1(2): 121-125.

Protan Laboratories Inc. 1987. Protan Biopolymers. Norway [NO]: Protan Laboratories, Inc.

Ratnani RD. 2011. Kemampuan Kombinasi eceng gondok dan lumpur aktif untuk menurunkan pencemaran pada limbah cair industri tahu. Momentum. 8(1): 1-5.

Ratnawulan A, Noor E, Suptijah P. 2018. Pemanfaatan Kitosan dalam Daur Ulang Air sebagai Aplikasi Teknik Produksi Bersih. Jurnal Pengolahan Hasil Perikanan Indonesia. 21(2):276-286.

Renault F, Sancey B, Badot PM, Crini G. 2009. Chitosan for coagulation/flocculation processes - An eco-friendly approach. European Polymer Journal. 45: 1337-1348. Ruhmawati, Sukandar T, Karmini D, Roni SR. 2017. Penurunan kadar total suspended solid (TSS) air limbah tahu dengan metode fitoremediasi. Jurnal Permukiman. 12(1):25-32.

Sinardi, Soewondo P, Notodarmojo S. 2013. Pembuatan karakterisasi dan aplikasi kitosan dari cangkang kerang hijau (Mytulus viridis linneaus) sebagai koagulan penjernih air. Konferensi Nasional Teknik Sipil. 7: 33:38.

Suharto. 2011. Limbah Kimia dalam Pencemaran Udara dan Air. Yogyakarta (ID): ANDI.

Syamsumarsih D. 2011. Penggunaan biji asam jawa (Tumarindus Indoca L.) dan biji kecipir (Psophcarpus Tetragonolobus L.) sebagai koagulan alami dalam perbaikan kualitas air tanah. [Skripsi]. Jakarta (ID): Universitas Islam Negeri Jakarta.

Wardhani K, Widyastuti, Hadiwidodo M, Sudarno. 2014. Khitin cangkang rajungan (Portunus pelagicus) sebagai biokoagulan untuk penyisihan turbidity, TSS, BOD dan COD pada pengolahan air limbah farmasi PT. Phapros Tbk, Semarang. Jurnal Teknik Lingkungan. 3(4): 1- 6.

Yudhistira B, Andriani M, Utami R. 2016. Karakterisasi limbah cair industri tahu dengan koagulan yang berbeda (asam asetat dan kalsium sulfat). Journal of Sustainable Agriculture. 31(2):137-145.

Yuliastri IR. 2010. Penggunaan serbuk biji kelor (Moringa oleifera) sebagai koagulan dan flokulan dalam perbaikan kualitas air limbah dan air tanah. [Tesis]. Jakarta (ID): Universitas Islam Negeri Jakarta. 